\title{
Integration of study material in the problem-based learning method
}

\author{
S Becker, MSocSc (Nursing), School of Nursing, UFS \\ MJ Viljoen, DSocSc (Nursing), Head of the School, School of Nursing, UFS \\ Y Botma,PhD, Associate Professor, School of Nursing, UFS \\ IJ Bester,BSc (Hons) Lecturer, Department of Biostatistics, UFS
}

\section{Abstract}

Throughout the world educators are starting to realise that integrated curricula reflect the "real world". Students learn how to integrate theory appropriately with practice and it stimulates higher order thinking skills. Problem-based learning (PBL) was used as a learning strategy in an integrated undergraduate programme. A quantatative nonexperimentald design, a survey, was used to determine how problem-based learning influences integration of learning by the students. Using a purposive sampling method all the first-year nursing students (43) at the University of the Free State participating in the programme were included in the study. Data was collected by means of a student perception questionnaire (SPQ).

PBL does contribute to an integration of learning. All the students agreed that community problems were brought to the classroom and that theory and practice were complementary. Students also indicated that PBL enhanced gathering of information from various sources and a holistic view of a situation. Problem-based learning also increased the ability to consider problems from various viewpoints and taught students clinical reasoning. Certain aspects of integration still seem to be a problem as $42 \%$ of the students indicated that subjects were not related, $21 \%$ that subjects were not integrated and $37 \%$ that scenarios were not realistic. This might be attributed to the fact that only the nursing subjects were taught by means of PBL. It is recommended that scenarios be revised to make them more realistic and that traditional subjects such as Anatomy, Microbiology and Chemical Science be integrated with nursing subjects by means of problem-solving themes, to form a meaningful core curriculum.

\section{Opsomming}

Opvoeders, dwarsoor die wêreld, begin agterkom dat 'n geïntegreerde kurrikulum die "ware wêreld" weerspieël. Studente leer nie alleen hoe om teorie en praktyk te integreer nie, maar hoërordedenkvaardighede word ook aangeleer. Probleemgebaseerde leer (PBL) is in ' $n$ geïntegreerde voorgraadse kurrikulum as 'n leerstrategie gebruik. 'n Kwantitatiewe nie eksperimentele navorsingsontwerp, ' $n$ opname, is gebruik om die effek van probleemgebaseerde leer as ' $n$ onderrigstrategie op die integrasie van leer te beskryf. Alle eerstejaar verpleegkundestudente (43) aan die Universiteit van die Vrystaat is deur middel van ' $n$ oordeelkundige steekproefmetode by die studie ingesluit. Data is versamel deur die student persepsie vraelys (SPQ) te gebruik.

PBL dra by tot integrasie van leer. Al die studente het saamgestem dat gemeenskapsprobleme na die klas gebring is en dat teorie en praktyk mekaar gekomplimenteer het. Studente het ook aangedui dat PBL die versameling van inligting uit verskeie bronne verbeter en ' $n$ holistiese siening van die situasie verskaf het. Dit het ook die vermoë om probleme vanuit verskillende oogpunte te sien verbeter en studente kliniese beredenering geleer. Sekere aspekte van integrasie blyk steeds ' $n$ probleem te wees. Studente het aangedui dat vakke nie verband hou nie ( $42 \%$ ), vakke is nie geïntegreer is nie ( $21 \%$ ) en scenario's nie realisties was nie (37\%). Dit kan toegeskryf word aan die feit dat slegs verpleegkundevakke deur middel van PBL aangebied is. Daar word aanbeveel dat tradisionele vakke soos Anatomie, Mikrobiologie en Chemiese Wetenskappe deur middel van probleemoplossingstemas in ' $n$ betekenisvollekern kurrikulum geïntegreer moet word. Scenario's behoort ook hersien te word om hulle meer realisties te maak.

\section{Introduction}

The progressive educational movement of the 1920 s advocated curricular integration through themes to increase relevance and help students see relationships between subjects. Since the 1960 s this phenomenon has changed and the trend in curricula has started to become mainly discipline-oriented (Drake, 1993:23).

Discipline orientation, along with the behavioural-objectives model of Ralph Tyler (Quinn, 1989:236-237; Greaves, 1987:2), influenced and dominated education throughout the world. According to these authors Taba and Wheeler took up Tyler's notion of behaviourism and this led to a generic systematic model of curriculum development consisting of four main components: objectives, content, method and evaluation. This model has dominated education to a large extent over the past thirty years. Criticism of overloaded curricula, emphasis on content coverage, fragmented and artificial learning, duplication among disciplines or subjects and the behavioural-objectives model with its authoritarian stance, led educators of the 
A paradigm shift has started to take place and the changing nature of society is currently reflected in various innovative curricula throughout the world. Control by means of behaviourist objectives is being replaced by freedom in learning, while the process of learning is replacing the emphasis on the product of learning. A holistic philosophy of learning has started to replace the fragmented, divisional and disciplineoriented stance of education. A focus on real-life scenarios with increased emphasis on the community is gaining ground (Quinn, 1989:235). Educators are starting to realise that integrated curricula allow subjects to be connected in ways that reflect the real world, putting curricula within the context of human experience. Kruger (in Mostert, 1985:65) agrees that "the problems that people encounter do not come in subjects or disciplines, but in situations in which man has to act according to his entire frame of reference ...".

Drake (1993:2) quotes Beane who believes that disciplines are an artificial creation humankind aimed at organising its world and are often defined by political needs. This phenomenon causes students to learn in a fragmented and disconnected manner "that has little resemblance to real life". Integration refers to phenomena (concepts) that are perceived as holistic (for example as portrayed in a conceptual framework) and to components (concepts) that interact with one another and with their environment (context). Integration allows for subjects to be connected in ways that reflect the real world, making curricula contextual of human experience. Situations or problems, rather than subjects, are the basis for deciding what to teach, while concepts, principles and theories from the sciences (relevant physical, biological, social sciences) are used. The curriculum is organised around problems rather than disciplines in order for students to learn how to integrate theory with practice appropriately and to stimulate higher order thinking skills (Drake, 1993:44; White \& Evan, 1991:24; 50; Evan \& White, 1989:9-10; 25; 35; Walton \& Matthews, 1989:555; Greaves, $1987: 30 ; 52)$.

In order to confront real-Iife problems Greaves (1987:30) recommends that "the curriculum, should incorporate the relevant applications of knowledge whereby the student can develop the necessary insights and clinical judgements which take account of that knowledge ". Providing students with potential problems to deal with can do this. The focus of the study becomes problems that will require input from various subjects, disciplines or experts. This strategy encourages inquiry, provides a stimulating environment for learning, integrates theory and practice, as well as various subjects in a meaningful way (Greaves, 1987:30; 52). Because integrated curricula make use of real issues and problems, higher-order thinking skills are stimulated and discipline boundaries start to dissolve. The human brain searches for interconnections and patterns to make sense of his world, therefore it makes sense to teach through connections (Drake, 1993: 2-3).

Change, proliferation of knowledge, pressure on educators to cover content of overloaded curricula in record times and frustrated, ill-prepared students have led to an increase in the use of more self-directed instructional methods in tertiary education. One such method is problem-based learning (PBL). Foldevi, Sommanson and Troll (1994:474) view problem-based learning as an alternative to the top-down transfusion of facts; instead it is "a ground-up engendering of active skills in young, eager and naturally problem-solving minds". The essential characteristics of PBL include: curricular organisation around problems rather than disciplines; an integrated curriculum rather than one separated into basic sciences and clinical science components, and an inherent emphasis on cognitive skills as well as on knowledge (Walton \& Matthews, 1989:555).

\section{Operational definition Problem based learning}

A method of learning or teaching that emphasises the study of clinal cases, small discussion groups, collaborative independent study, hypothetic-deductive reasoning and a style of faculty direction that concentrates on group process and small group learning (Vernon \& Blake 1993: 550-551)

\section{Problem statement}

In the late 1980s staff of the School of Nursing at the University of the Free State, became alarmed by the fact that their students demonstrated lack of retention and integration and retention of basic sciences with the clinical context (Fichardt, 1996:16). It also became clear that the ever-increasing expansion of scientific knowledge in big tertiary complexes no longer matched the community's demands for relevance and affordability (Mazwai, 1996:6). Although scientific nursing (the nursing process approach, which consists of assessment, planning, implementation, evaluation and recording) had replaced the task-centred approach to a large extent, learning was still fragmented, as subjects in the curricula were divided by traditional subject boundaries.

The School of Nursing developed an integrated and processoriented curriculum model with emphasis on community-based nursing and a philosophy of problem-based learning. An action-research model was used to monitor the implementation of the curriculum. Problem-based learning was phased in year by year and the process was completed in the year 2000 . The first-year (undergraduate) nursing course was taught by means of problem-based learning, traditional lectures and video-assisted instruction. Nursing Theory and Nursing Practice were taught by means of problem-based learning and Anatomy by means of video-assisted instruction, while the remaining subjects (Chemistry, Physiology, Microbiology I, Microbiology II, Psychology and Sociology) were taught by means of traditional lectures. A "hybrid" model was thus adopted. Nursing subjects were taught in an integrated and problem-based manner, while the remaining subjects were taught in a traditional manner.

As a strategy for learning problem-based learning seemed appropriate, as it was being introduced successfully at various health faculties worldwide. It seemed that this learning strategy succeeded in overcoming student passivity, integrating basic science with clinical courses and promoting lifelong learn- 
ing on the part of students (Eisenstaedt, Barry \& Glanz, 1990:511). Drake (1993:2-3) adds that problem-based learning stimulates higher-order thinking and causes discipline boundaries to dissolve. One of the many educational objectives described by Barrows (1983:3077-3080) is the acquisition of a basis of knowledge that is better retained, integrated from all the relevant disciplines, applicable in the clinical context and extended into the future through self-directed study.

In comparing PBL with the lecture-based analogue, Donner and Bickley (1990: 881), noticed that PBL goes beyond the lecture because in PBL basic medical sciences are learned concurrently (integrated into the same programme) and in the con- text of a health problem. This means that basic sciences and theory and practice are integrated in a meaningful way. Effective integration among the different disciplines, and learning within the context of problems rather than in the context of disciplines are one of the main aims of problem-based-learning (Walton \& Matthews, 1989:545). Albanese and Mitchell (1993:53) and Gist (1992:8) agree that basic science, clinical knowledge and clinical reasoning skills should be integrated to help students acquire critical thinking skills.

Furthermore problem-based learning addresses the request by the South African Nursing Council to integrate various fields of study in the undergraduate programme. It also has many interfaces with the National Qualifications Framework, for example the activation and construction of problem-oriented se-

\section{Figure 1 : The effect of PBL on the intergration of learning}

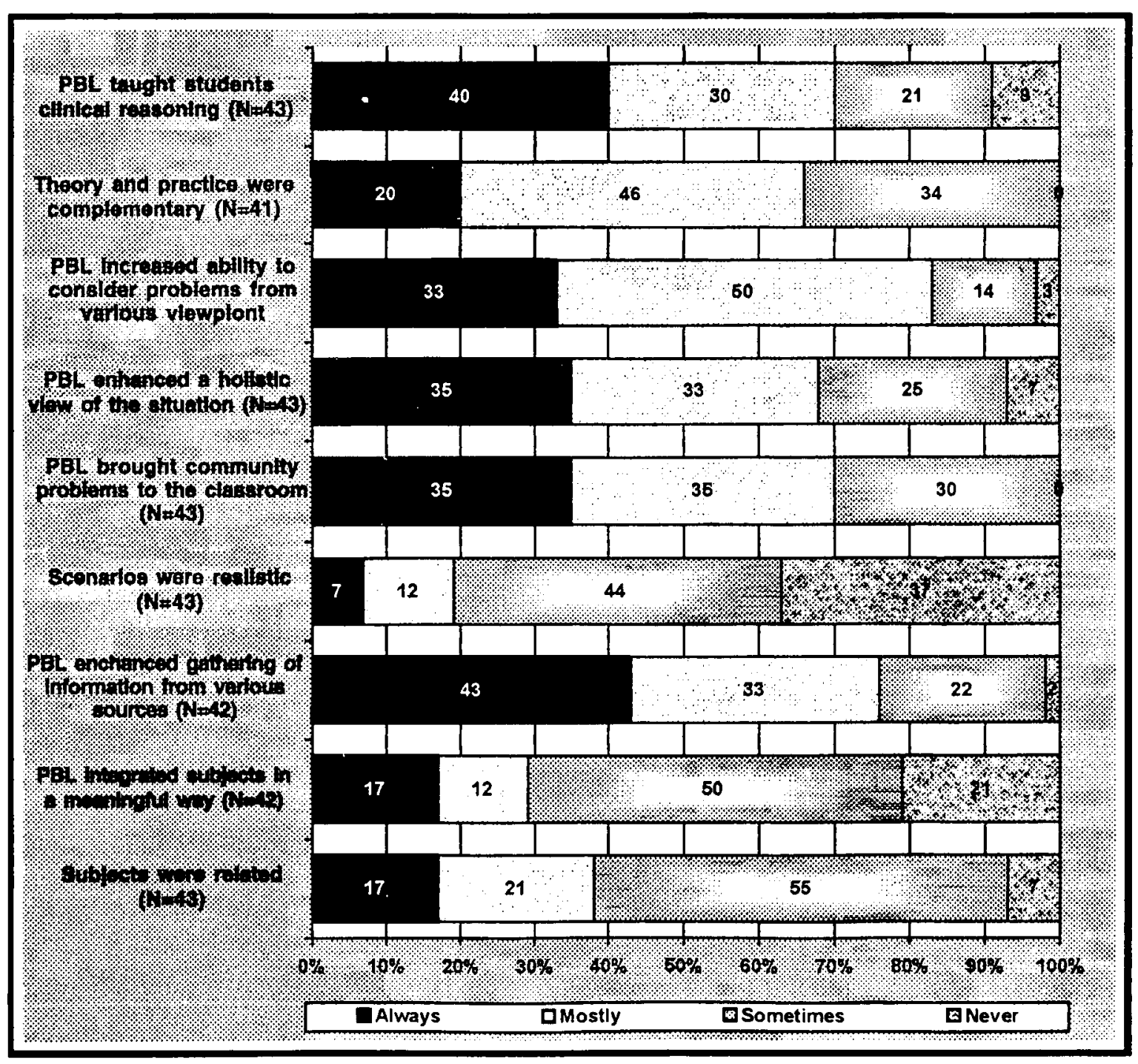


mantic networks to enhance general abilities such as communication, problem-solving and learning strategies, contextual cues derived from professionally relevant problems and the fostering of epistemic curiosity and integrated learning (South African Interim Nursing Council, 1996:4; Republic of South Africa, 1995:5-28). The question however arises whether problem-based learning leads to integration of learning on the part of the students.

\section{Aim}

The purpose of this research was to explore the integration of study material in the problem based learning method.

\section{Research methodology}

A survey, which is a quantatative, non experimental design, and purposive sampling method was used (Burns and Grove 1997: 781) This method enhances the systematic and unbiased collection of information. The sample consisted of all the 1998 first-year nursing students at the University of the Free State following the problem-based learning strategy for the first time. Data were collected by means a student perception questionnaire (SPQ). It was developed by the researcher, with the help of two faculty members with experience in the development of research instruments and three biostaticians. Questions related to perception of the course, group work, aspects of the method of teaching they enjoy most and least, ways in which the course could be improved and advice given to patential new-comers were included.

The SPQ included various open-ended as well as structured questions. The structured questions mainly supplied possible responses from which students had to choose one or more items. Interpretative reliability was used, as the aim was to reach consensus among the experts after the questionnaire had been presented to them for scrutiny. Interpretative reliability refers to the extent "to which each judge assigns the same category to a given unit of data" (Burns \& Grove 1997:771). A statistician of the Department of Biostatistics did the statstical analysis of the close-ended questions, while the researcher analysed the open ended questions. Descriptive statistics, namely frequencies and percentages for categorical data and means and medians for numerical data were calculated.

\section{Results}

Figure 1 indicates data collected with the SPQ questionnaire. Seven per cent of the students indicated that subjects were never related to one another, while the majority $(83 \%)$ indicated continuos relation of subjects to one another to a greater or lesser extent. The majority of students $(79 \%)$ indicated that PBL integrates subjects in a meaningful way, while $21 \%$ of the students did not agree with this statement. Ninety-eight per cent of the students felt that PBL enhanced their ability to gather information from other sources. More than half of the students $(63 \%)$ indicated that the scenarios were realistic, while $37 \%$ indicated otherwise. All the students (100\%) indicated that PBL brought community problems to the classroom. Except for $7 \%$ of the students, all the other students (93\%) agreed that PBL enhances a holistic view of the situation. Most (97\%) of the students agreed that PBL increases one's ability to consider problems from various viewpoints. All the students $(100 \%)$ indicated that theory and practice were complementary. Ninety-one per cent of the students agreed that PBL teach students clinical reasoning, while $9 \%$ disagreed with this statement. Various positive remarks were made by individual students such as: "PBL gives a good holistic picture", "my scientific and analytical thought skills improved", "I learned problem-solving skills".

\section{Recommendations}

Certain aspects of integration still seem to be a problem as more than $42 \%$ of the students indicated that subjects were not related, $21 \%$ that subjects were not integrated and $37 \%$ that scenario's were not realistic. This might be attributed to the fact that only the nursing subjects were taught by means of PBL. It is recommended that scenarios be revised to make them more realistic and that traditional subjects such as Anatomy, Microbiology and Chemistry be integrated with nursing subjects by means of problem-solving themes to form a meaningful core curriculum. Only then can this programme really be called a truly problem-based programme. In this way disciplinary boundaries will be transcended and a "real world" approach adopted.

\section{Conclusion}

PBL does contribute to an integrated curriculum. All the students agreed that community problems were brought to the classroom and that theory and practice were complementary: Students also indicated that PBL enhanced gathering of information from various sources and a holistic view of a situation. Problem-based learning also increases the ability to consider problems from various viewpoints and taught students clinical reasoning.

According to Drake (1993:51) there is no "right way" to teach. To build an integrated curriculum, educators must let go of old models of curriculum design and dare to leave their comfort zones, as old models will not work for this process.

\section{References}

ALBANESE MA \& MTCHELL S 1993: Problem-based leaming: a review of literature on its outcomes and implementation issues. Academic Medicine, 68(1):52-81.

BARROWS HS 1983: Problem-based, self-directed learning. Journal of Medical Education, 250:3077-3080.

BURNS N \& GROVE SK 1997: The practice of nursing research, conduct, critique and utilization. Philidelphia: WB Saunders Company

DONNER RS \& BICKLEY H 1990: Problem-based learning: an assessment of its feasibility and cost. Human Pathology, 21(9):88I-885. 
DRAKE SM 1993: Planning integrated curriculum: the call to adventure. Alexandria: Association for Supervision and Curriculum Development.

EISENSTAEDT RS; BARRY WE \& GLANZ K 1990: Problem-based learning: cognitive retention and cohort traits of randomly selected participants and decliners. Academic Medicine, 65(9):551-512.

EVAN C \& WHITE R 1989: Teaching nursing: $a$ selfinstructional handbook. London: Chapman and Hall Ltd.

FICHARDT AE 1996: A problem-based education programme for registered nurses in advanced midwifery and neonatology. Unpublished doctor's thesis, Bloemfontein, University of the Orange Free State.

FOLDEVI M; SOMMANSSON G \& TRELL E 1994: Problembased medical education in general practice: experience from Linkoping, Sweden. British Journal of General Practice, 44:473-476.

GIST GL 1992: Problem-based learning: a new tool for environmental health education. Journal of Environmental Health. 54(5):8-13.

GREAVES F 1987: The nursing curriculum: theory and practice. London: Chapman and Hall Ltd.

MOSTERT IM 1985: Situasie-analise en die bepaling van doelstellings vir vakkurrikula. Pretoria: Raad vir Geesteswetenskaplike Navorsing.

MAZWAI EL 1996: Problem-based learning and communitybased education at UNITRA. 3rd International Symposium on Problem-Based Learning: Durban.

QUINN FM 1989: The principles and practice of nurse education. 3rd edition. London: Croom Helm Ltd.

REPUBLIC OF SOUTH AFRICA 1995: Ways of seeing the National Qualifications Framework. Pretoria: Human Sciences Research Council.

SOUTH AFRICAN INTERIM NURSING COUNCIL 199: A unified nursing education system for South Africa: a discussion document. Circular to all nursing schools, September: 1-2.

WALTON HJ \& MATTHEWS MB 1989: Essentials of problem-based learning. Medical Education, 23:542-558.

WHITE R \& EVAN C 1991: Clinical teaching in nursing. London: Chapman. 